\title{
Country-Level Size Effects in International Asset Pricing
}

\section{Crina Pungulescu}

Institute for Economic Forecasting - National Institute of Economic Research and Romanian Academy, Romania

| e-mail: crina_pungulescu@ipe.ro

Volume 11 No 1 (2021) ｜ ISSN 2158-8708 (online) ｜ DOI 10.5195/emaj.2021.230 | http://emaj.pitt.edu

\begin{abstract}
This paper ${ }^{1}$ investigates whether small markets offer higher risk-adjusted expected returns using a large set of developed and emerging markets over a time span of up to four decades. The results show that expected returns are significantly lower in larger markets, an effect more pronounced in emerging rather than developed countries. The relationship between size effects and the level of market segmentation in emerging countries is further explored in the context of financial market integration. The size premium is strong and persistent over time independently of the (fading) segmentation premium documented in the literature. Markets size effects remain statistically and economically significant in the presence of various control factors and account for up to $1 \%$ per year in terms of expected returns in emerging countries.
\end{abstract}

Keywords: Finance, Market Size, Emerging Markets, Market Integration, Capital Controls

\section{$(\mathrm{cc})$ EY}

New articles in this journal are licensed under a Creative Commons Attribution 3.0 United States License.

\section{UILIS D-Sente}

This journal is published by the University Library System of the University of Pittsburgh as part of its $\underline{\mathrm{D}-S c r i b e}$ Digital Publishing Program, and is cosponsored by the University of Pittsburgh Press.

${ }^{1}$ This research was supported by a grant of the Ministry of National Education, CNCS - UEFISCDI, project number PN-IIID-PCE-2012-4-0631. 


\section{Country-Level Size Effects in International Asset Pricing}

\section{Crina Pungulescu}

\section{Introduction}

Emerging financial markets resemble the (more) mature counterparts from developed countries in important ways. Expected returns in both developed and emerging markets appear driven by qualitatively similar factors among which momentum, size and value effects have received substantial evidence (see Fama and French, 1998; Rouwenhorst, 1999; Hou et al., 2011; Fama and French, 2012; Lambert et al., 2020). The robustness of these findings across many countries in different stages of development suggests that such factors could be linked to asset pricing in a fundamental way, rather than being abnormal and transitory market reactions.

Of these factors, size effects have been widely investigated using firm level data. Smaller firms have systematically offered higher risk-adjusted expected returns. The evidence, although not undisputed, establishes them, at the very least, as a recognised factor in the cross-sectional analysis of returns from the original paper of Banz (1981) to recent revaluations of the magnitude of the size factor by Lambert and Hübner (2015), Cakici et al. (2016) and Li (2021). Interpretations of the evidence on the size premium range from compensation for risk factors, firm characteristics, access to capital, inefficiency in the way markets incorporate information into prices to survivorship biases or even data snooping (see Rouwenhorst, 1999; Ferguson and Shockley, 2003).

Contrary to firm size effects that have been widely recognised and extendedly debated in the literature, country-level size effects received little attention. In the early 1990s, practitioners recognised that the smallest markets appear to systematically outperform the larger ones, a phenomenon dubbed the Small-Country Effect (Keppler and Traub, 1993).

This paper addresses the question of size effects at the country level (i.e. market size) in a comparative exercise across developed and emerging markets and asks whether smaller markets harbor a size premium, as well. Market size effects may be important for the strategic choices of international investors, that would make an initial selection of countries rather than of individual stocks. Evidence on market size effects is only incipient with respect to developed markets and especially scarce for emerging markets. The original findings of Keppler and Traub (1993) and Asness et al. (1997) for market indices in developed countries have not been confirmed in other data sets analyzed by Bekaert et al. (1997) and Harvey (2000). At present, size effects are well established in the literature at the firm rather than the country level. However, the question of aggregate, market size effects, especially in the context of emerging markets, becomes increasingly relevant both for international investment as well as from a market integration perspective.

Emerging markets achieved substantial progress over the last decades and offer an ideal environment for establishing the potential relationship between market size and market integration. Moreover, they provide increasingly attractive investment opportunities. They have taken decisive steps towards market development and financial liberalization often as part of more committed economic reforms. Restrictions to foreign ownership of assets have been gradually lifted in many emerging countries and the market share that is open to foreign investors has been growing steadily. Strongly correlated with the decline of capital controls, the average market capitalization in emerging markets has been increasing by more than $30 \%$ per year. Previous studies showed that market liberalization results in lower cost of capital, a development expected to have positive effects on investment and development in a country (see Bekaert and Harvey, 2000; Henry, 2000; Edison and Warnock, 2003; De Jong and De Roon, 2005). It appears that the significant segmentation premium that characterized emerging markets prior to their opening towards foreign capital, is eroding due to financial liberalization. This paper builds upon the existing evidence of size and segmentation effects and conjectures that market development is relevant for asset pricing independently of the segmentation premium (documented with respect to market opening). Traditionally, market development has been equated with increases in the size of the market and is arguably enhanced by market integration. The main question here is whether the observed increase of market size has an impact on expected returns. To answer it, the traditional relationship of the International Capital Asset Pricing Model (I-CAPM) is extended by an additional factor, a proxy for market size. Using the share of market capitalization of the domestic index in the world market as a proxy for market size, the presence of size effects on expected returns is investigated for a set of developed and emerging countries, for a time span of up to four decades. Negative and significant estimates of the coefficients of the market proxy are interpreted as evidence of market size effects on the cost of capital, larger markets offering lower returns. The results show that expected returns fall significantly as market size increases, implying that the cost of capital is larger in smaller markets.

As market integration is expected to play a significant role in this result and size and segmentation effects are closely related, they should be investigated jointly and compared in terms of their particular effects on expected returns. Including a segmentation proxy, the intensity of capital controls for emerging markets does not affect the magnitude and significance of the market size coefficients. The relationship uncovered between expected returns and market size is strong and robust, over and above the previously documented impact of direct market segmentation. For the composite index of all emerging markets in the sample, expected returns decrease by $1 \%$ per year as market size increases. The (composite) segmentation effect on expected returns has virtually faded in this sample. The information content of the market size proxy appears to outweigh overwhelmingly that of the direct segmentation proxy, the intensity of capital controls. 
Segmentation has a secondary (indirect) effect on expected returns, through increasing the country's systemic risk, i.e. its beta relative to the world market portfolio. Bekaert and Harvey (2000) find that postliberalization world market betas are higher and De Jong and De Roon (2005) show that betas increase as countries become less segmented from the world market, i.e. the intensity of capital controls decreases. When the world market betas are allowed to vary over time as a function of the segmentation variable as well as of the size variable, the impact on the expected returns through this indirect (beta) channel is more pronounced for the direct segmentation variable than for the market size proxy.

The remainder of this paper is structured as follows: Section 2 presents the data sets used in this study, for developed and emerging markets together with the main proxy variables for size and segmentation. Section 2 is named as the Data. Section 3 presents the methodology and reports empirical evidence on the presence of size effects comparing developed and emerging markets. Section 3 is named as the Empirical Results. Finally, Section 4 reviews the main findings which is named as Conclusion.

\section{Data}

This section introduces the variables together with their various data sources and particularly, compares the dynamics of two key indicators of financial liberalization (the intensity of capital controls) and market integration (the market size).

\section{Return Indices and Global Risk Factors}

The main data, monthly United States (US) Dollar total returns indices and market capitalization figures for 61 countries are obtained over the period January 1973 September 2014, using Datastream's total market indices and in their absence, other broad market indices (thus including 5 more countries: Bahrain, Estonia, Iceland, Saudi Arabia and Zimbabwe). The 61 countries are divided into 2 groups: 'developed', i.e. the 34 members of the Organisation for Economic Cooperation and Development (OECD) and 'emerging' countries. The risk-free rate is the one-month US Treasury Bill rate from Ibbotson and Associates Inc., available on Kenneth French's website ${ }^{2}$ and MSCI World market returns in US Dollars are taken as a proxy for the global market returns.

In order to compare the market size effects with the previously documented segmentation effects, an alternative database is needed to compute the intensity of capital controls. Total return indices and market capitalization figures in US Dollars are obtained from the Standard \& Poor's Emerging Market Database (EMDB) ${ }^{3}$, for a panel of 38 emerging markets as well as several aggregate indices: A Composite Index for all the countries in the dataset and regional indices for Asia, Europe-Mid-East-Africa, Europe, Eastern Europe, Latin America and Mid-East-Africa. The subsection named The Intensity of Capital Controls and Market Size provides detailed information on the computation of the

${ }^{2} \mathrm{http} / / / \mathrm{mba} . t u c k . d a r t m o u t h . e d u / p a g e s /$ faculty/ken.french/ data_library.html

${ }^{3}$ available from Datastream. intensity of capital controls. The dataset covers the period December 1975 - September 2014, though for a number of countries coverage starts in December 1988 and ends in October 2008. This secondary database (despite its uneven coverage) also serves as a robustness check, as all estimations are repeated using this data4. Table 1 details the Datastream and respectively EMDB coverage of return data for all the countries in the dataset as well the OECD accession dates for the developed countries in the sample.

Table 1: Data Availability

\begin{tabular}{|c|c|c|c|c|c|}
\hline & & & & & Ot(I) \\
\hline & Triloth: & Talotix & Thenthis. & Tal0this. & Rewssiut \\
\hline Agretenini & प्राप्र & 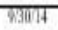 & $712 \times 15$ & Tostron & \\
\hline Austenla & 13177 & 93074 & & & 6971 \\
\hline Aiblia & เหเาง & 93074 & & & Q2961 \\
\hline Buatnit & 22610 & 93014 & $120 \%$ & 630/4 & \\
\hline Bely:an & 13:77 & 93074 & & & 97361 \\
\hline Dlaxi & $720 \% 4$ & 93024 & 112875 & 10:3L6 & \\
\hline Catadia & เมเาง & 93014 & & & 47061 \\
\hline Chile & กับบท & 93014 & $11 / 2875$ & 1031\% & क्षाओ \\
\hline Cim & S3154 & 93074 & 102093 & J03เดs & \\
\hline Colimba & 123193 & 93014 & 123184 & 89171 & \\
\hline Cath fetpubitic & 123094 & 93074 & 123109 & 1031138 & 122195 \\
\hline Detunatk & เมดา & 93014 & & & 5w061 \\
\hline Ens & 93006 & 93614 & เมเติ & 10310\% & \\
\hline Elitata & I3aps & 93004 & & & 12910 \\
\hline Fitatial & $331 / 8$ & 93014 & & & $1 / 869$ \\
\hline Fanat & เมเก] & 93074 & & & 8961 \\
\hline Getraity & 13177 & 93074 & & & 92761 \\
\hline Gireste & I3L & 93074 & 112875 & 103เดล & क27:6 \\
\hline Hianary & |23เต] & 93014 & 123193 & ј03เด & 5796 \\
\hline leting & 731402 & 93074 & & & \\
\hline $\ln 5$ & 123193 & 93014 & 1112875 & 1031198 & \\
\hline Inanesia & $430 \%$ & 93014 & $1220 \mathrm{ks}$ & J031ว & \\
\hline Ireluns & 13173 & 93074 & & & 81761 \\
\hline linal & 123193 & 93014 & 13197 & J0310 & 97710 \\
\hline luly & 1317? & 93014 & & & $3 / 2962$ \\
\hline latat & เมเา! & v3014 & & & 42864 \\
\hline Junlai & 63006 & v3ent & Iมเศ & 93014 & \\
\hline Kivea & 930,17 & 93014 & 1128795 & jo3La & 121296 \\
\hline Kiwail & 12310 & 93014 & IaLa6 & 92014 & \\
\hline Laentoung & เaเต & 93074 & & & |1276| \\
\hline Malusa & 13186 & 93014 & 123144 & 103121 & \\
\hline Mesiio & 53UK & 93014 & 11.2875 & 10316\% & $518 \% 4$ \\
\hline Manuso & 123004 & 93014 & 13197 & 103เวิ & \\
\hline Nethethans & 131917] & 93074 & & & 11แ3ต \\
\hline New Ztiund & 12088 & 93014 & & & s:yns \\
\hline Nigraia & $9: 309 \%$ & 93014 & I3LRS & 93014 & \\
\hline Neway & 1346 & 93074 & & & 7461 \\
\hline Oman & 103105 & 93074 & 1296 & W30/4 & \\
\hline Patsat & เ23เต] & 93014 & 123124 & 03014 & \\
\hline Pen & $131 / 94$ & 93074 & ด30\%1 & 1031178 & \\
\hline Pilippites & $1130 \mathrm{Bg}$ & 93014 & |2งเห4 & 1031\% & \\
\hline Powatd & 13194 & 93674 & [23Lิด] & 10311日ล & \\
\hline Rurianal & $131 / 6$ & 93004 & & & \\
\hline Qular & |23เ03 & 93074 & 13106 & $930 / 4$ & \\
\hline Rusii & $1309 \mathrm{~s}$ & 93014 & 13197 & 1031/月5 & \\
\hline Sadi Andua & เ23เด? & 93074 & 13098 & $030 / 4$ & \\
\hline Slovak Repuahăs & 13197 & 93014 & & & 1214060 \\
\hline Slveraia & $12319 \mathrm{~h}$ & 93074 & & & $721 / 6$ \\
\hline Seull Africa & 13193 & 93074 & $131 / 24$ & 103นด & \\
\hline Soin & $33 \mathrm{LR} 7$ & 93014 & & & 8961 \\
\hline Sin Lathis & 123193 & 93074 & 93093 & 930/4 & \\
\hline Sirtaten & 120.82 & จ3014 & & & \\
\hline Swilintan! & 1317? & 93014 & & & Q2861 \\
\hline Tuikati & $9318 \pi$ & 93074 & 1231:4 & 103198 & \\
\hline Thulat & 13017 & 93074 & 12.3175 & 103126 & \\
\hline Tultey & $6: 30 \%$ & 93674 & 123LR & 163186 & k26i \\
\hline Urilst Atib Ematici & 123601 & 939074 & I3LA6 & $990 / 4$ & \\
\hline Unibed Kinudata & เด1/7\} & 93014 & & & $\$ 261$ \\
\hline linitil Sultex & 131/7 & 93074 & & & 47261. \\
\hline Vansacal & 123เ9] & 933074 & I23LAX & y3om? & \\
\hline Zimbitrit & 1221785 & josioi & 112875 & 1031\%3 & \\
\hline
\end{tabular}

Source: Authors' own compilation

This table provides information on data availability (dates of first and last observations) for each of the 61

\footnotetext{
4 From this point onwards, the two data sources are referred to as Datastream and EMDB.
} 
countries in two alternative databases (DATASTREAM and EMDB). The last column includes the accession date for members to the Organization for Economic Cooperation and Development (OECD).

A set of global economic risk variables similar to the ones suggested by Ferson and Harvey (1993) are used as controls:

1. Currency Risk, FX, the percentage change in a broad index of foreign exchange value of the US Dollar against a trade-weighted basket of currencies of important trading partners of the US ${ }^{5}$. The index reflects the price of the US Dollar in terms of the foreign currencies basket, with a higher value corresponding to an appreciation of the US Dollar.

2. Inflation Risk, G7 INFL, the monthly change in the weighted average of the consumer price index (CPI) of the G7 countries (Canada, France, Germany, Italy, Japan, UK and US), where the weights are given by their relative Gross Domestic Product (GDP= shares.

3. Interest Rate Risk, G7 IR, a proxy of global investment opportunities, computed as a weighted average of shortterm real interest rates in G7 countries (with weights given by their shares in the G7 GDP).

4. Global Credit Risk, CR RISK, the percentage change in the spread between the 3-month Eurodollar rate and the 3-month US Treasury Bill yield.

5. Global Output Risk, G7 PROD, the percentage change in the monthly producer price index (PPI) for the manufacturing sectors in $\mathrm{G} 7$ countries.

6. Oil \& Gas, the change in the monthly world price index for oil and gas, as a measure of economic risk.

The currency risk, FX, is computed based on the broad index of the US Dollar's foreign exchange, developed by the Federal Reserve. All other risk variables are computed using data from Datastream. An additional control variable is a measure of composite country risk taken from the International Country Risk Guide (ICRG). ICRG produces monthly risk indices based on political, financial and economic factors as well as a composite index, a linear combination of the former three, where political risk (associated with the country's willingness to pay) accounts for $50 \%$ of the composite index and financial and economic risk (reflecting the country's ability to pay) have each a weight of $25 \%$ in the aggregate index. A higher value of the index is associated with lower risk. The ICRG methodology is described in Erb et al. (1996). Also, for countries covered by the Emerging Market Database a direct measure of segmentation is available, namely the intensity of capital controls, presented in full detail in the next section.

\section{The Intensity of Capital Controls and Market Size}

Capital controls - most specifically restrictions to foreign ownership - are quantified in a unitary fashion for a large number of emerging countries in Standard \& Poor's Emerging Markets Database through two categories of indices, the S\&P global index and the investable index. The global index captures the overall

\footnotetext{
${ }^{5}$ The broad index of the dollar's foreign exchange value includes 35 currencies until the introduction of the euro, and 26 currencies representing important trading partners for the US, after 1999 (see Leahy, 1998).
}

stock market performance of emerging countries without taking into account restrictions on foreign investors' ownership of equities. It considers all actively traded securities and aims to cover $60 \%$ to $75 \%$ of the total market capitalization of a country, after exclusions due mainly to government ownership and cross-holdings of other constituents to avoid double counting. The investable index is constructed to reflect the international availability of emerging markets to foreign investors. It is a fraction of the global index trimmed based on several rules, with respect to market capitalization, liquidity, market level constraints (reflecting the ability of foreign investors to buy and sell shares and repatriate capital, capital gains and dividend income) as well as industry and corporate level restrictions of foreign ownership. These direct barriers to foreign ownership create an internal division in the emerging financial markets between an internationally open submarket (where foreign investors are allowed to invest) and a restricted market operating exclusively for the domestic investors. The global and investable indices provide an objective measure of the intensity of capital control (Edison and Warnock, 2003). The measure is given by the relative difference between the market capitalizations of the two indices, as follows:

$I_{i, t}=1-\frac{M C_{i, t}^{I}}{M C_{i, t}^{G}}$,

Where $M C_{i, t}^{I}, M C_{i, t}^{G}$ are the market capitalizations at time $t$ of country $i$ 's global and investable indices respectively. The intensity of capital controls takes values between 0 (perfect openness of capital market to foreign ownership) and 1 (complete segmentation of domestic capital market). This value is taken as a proxy for direct market segmentation. However, being derived from the investable indices, the intensity of capital controls essentially accounts for revealed foreign ownership restrictions. Many forms of capital controls such as taxes on capital inflows or unremunerated reserve requirements (such as the Chilean encaje) are not directly incorporated in this measure. This circumvents the problem of quantifying the effectiveness of various forms of capital controls, but also makes the measure relevant particularly to capital markets rather than to other sectors of the economy. Moreover, the intensity of capital controls focuses directly on the availability of assets for foreign ownership whereas market integration occurs when foreign investors make effective use of the opportunity offered by the emerging market. To gain additional insight into the effective process of market integration, the dynamics of the intensity of capital controls is contrasted with the market capitalization for the emerging countries in the sample.

Table 2 reports summary statistics for both variables as well as the pairwise correlations between market segmentation and market size. The aggregate indices are computed for all countries (Composite) as well as several regions: Asia, Europe Mid East Africa, Europe, Latin America and Mid East Africa. The Composite intensity of capital controls is gradually declining from 0.87 to a low value of 0.29 , whereas market size follows an opposite trend over the period. The correlation between the two variables is strongly and significantly negative, 0.56. Capital controls decrease in Asia, whereas Europe, Mid East and Africa experience periods of slight reversal of the process of financial liberalization. Latin America, 
as a region achieves gradually relatively low levels of segmentation (with respect to restrictions to foreign ownership) in the early 1990s and maintains this status in the following years. Both Asia and Latin America show strong negative correlations between market segmentation and market size.

The evolution of market segmentation is different across the emerging markets included in the database. Many countries (Bahrain, Egypt, Greece, Israel, Malaysia, Morocco, Peru, Poland, Turkey, Slovakia and South Africa) have a medium/low and fairly stable level of segmentation. Jordan, Philippines, Sri Lanka and Zimbabwe maintain relatively strict capital controls. The rest of the countries are divided over the way they open up their market to foreign investors: the intensity of capital controls is gradually decreasing in China, India, Thailand and Venezuela and drops decisively in Argentina, Chile, Czech Republic, Korea, Mexico and Qatar (for instance). The measure of market segmentation is mostly negatively correlated with market size $^{6}$. This suggests a possible link between the dynamics of size and segmentation. One intuitive scenario could be that foreign capital has been quick to pick up on decrease in market segmentation in many countries. Should this be the case, size and segmentation effects can be expected to reinforce each other. However, size and segmentation effects may exist independently of each other. A small and/or restricted market can maintain a high cost of capital if its capital needs are inadequately met, even in the case when market size and segmentation do not evolve together. Moreover, market segmentation is only one of the many factors that can be related to the dynamics of market capitalization. There are also cases when segmentation and market size are positively correlated such as Bahrain, the Czech Republic, Kuwait, Poland, Qatar, Slovakia and the United Arab Emirates. In other countries (Israel, Jordan, Malaysia, Oman, Pakistan, South Africa, Taiwan, Venezuela and Zimbabwe), the market capitalization and the intensity of capital controls are not significantly correlated.
Table 2: Summary Statistics - Intensity of Capital Controls and Market capitalization (EMDB Data)

\begin{tabular}{|c|c|c|c|c|c|c|c|c|c|}
\hline & \multicolumn{4}{|c|}{ CAPTAL CONTROLS } & \multicolumn{4}{|c|}{$\begin{array}{l}\text { MARKET CADITALZZATION } \\
\text { (million \&) }\end{array}$} & \multirow[t]{2}{*}{ CORR } \\
\hline & Nem & Sin & Maz. & Obs. & Nem & Nin. & $\mathrm{N} 2 \mathrm{ar}$ & Obs. & \\
\hline Composite & 0.42 & 0.20 & 0.89 & 239 & 1196642 & 30333 & 6261160 & 287 & .0 .56 \\
\hline Latin America & 0.20 & 0.04 & 0.82 & 239 & 209581 & 8101 & 1087498 & 287 & -0.51 \\
\hline Asin & 0.52 & 0.14 & 0.92 & 239 & 657452 & 1852 & 3628745 & 287 & .0 .63 \\
\hline $\begin{array}{l}\text { Europe Mid East } \\
\text { Afica }\end{array}$ & 0.29 & 0.07 & 0.48 & 130 & 613751 & 191488 & 1692298 & 130 & 0.52 \\
\hline Europe & 0.14 & 0.02 & 0.33 & 131 & 232021 & 57795 & 721508 & 143 & .0 .41 \\
\hline Bastem Burope & 0.18 & 0.02 & 0.37 & 130 & 190460 & 22569 & 658680 & 130 & .0 .33 \\
\hline Nid Eas Afica & 0.38 & 0.05 & 0.62 & 130 & 370539 & 99998 & 988605 & 130 & 0.81 \\
\hline Argenting & 0.43 & 0.00 & 100 & 395 & 9716 & 83 & 35860 & 30,5 & .0 .73 \\
\hline Buhrin & 0.14 & 0.03 & 0.33 & 93 & 4907 & 1559 & 10502 & 189 & 0.20 \\
\hline Brail & 0.24 & 0.04 & 0.88 & 239 & 78866 & 2012 & 718884 & 305 & .0 .13 \\
\hline Challe & 0.32 & 0.01 & 0.86 & 239 & 20985 & 154 & 78992 & 305 & .0 .49 \\
\hline Chins & 0.66 & 0.25 & 0.95 & 181 & 213263 & 11949 & 1509995 & 181 & .0 .19 \\
\hline Colombia & 0.25 & 0.04 & 0.59 & 129 & 9673 & 285 & 54815 & 321 & .0 .61 \\
\hline Crech Republic & 0.34 & 0.00 & 0.72 & 123 & 8783 & 2079 & 25999 & 179 & 0.76 \\
\hline Egypt & 0.18 & 0.02 & 0.40 & 141 & 12090 & 1901 & 42915 & 142 & .0 .73 \\
\hline Greece & 0.08 & 0.00 & 0.38 & 167 & 11752 & 245 & 92542 & 323 & .0 .88 \\
\hline Hingary & 0.08 & 0.00 & 0.45 & 179 & 11819 & 659 & 34482 & 179 & .0 .60 \\
\hline Indiin & 0.59 & 028 & 0.80 & 192 & 60074 & 527 & 598760 & 395 & .0 .69 \\
\hline Incobeeila & 0.26 & 0.00 & 0.74 & 218 & 21272 & 2254 & 64011 & 227 & .0 .15 \\
\hline lanel & 0.01 & 0.00 & 0.03 & 142 & 40221 & 13692 & 99919 & 142 & 0.10 \\
\hline Jordan & 0.63 & $0.4 ?$ & 0.74 & 155 & 4507 & 335 & 20550 & 44 & .006 \\
\hline Korea & 0.35 & 0.03 & 0.93 & 202 & 109227 & 324 & 746068 & 395 & .0 .50 \\
\hline Rumait & 0.05 & 0.00 & 0.33 & 93 & 58381 & 34757 & 127198 & 105 & 0.72 \\
\hline Naldyyia & 0.13 & 0.03 & 0.35 & 239 & 60006 & 6811 & 183291 & 287 & 0.02 \\
\hline Nerico & 0.11 & 0.00 & 0.89 & 239 & 52411 & 608 & 212227 & 305 & .0 .11 \\
\hline Noroccco & 0.14 & 0.03 & 0.37 & 141 & 9965 & 3673 & 31172 & 142 & 0.53 \\
\hline Nigeria & & & & 0 & 323 & 168 & $49 ?$ & 61 & \\
\hline Oman & 0.11 & 0.03 & 0.30 & 93 & 4795 & 1230 & 12001 & 189 & 0.06 \\
\hline Pahiston & 0.37 & 0.11 & 0.85 & 128 & 5103 & 495 & 15416 & 358 & 0.00 \\
\hline Pen & 0.12 & 0.03 & 0.28 & 182 & 9034 & 1936 & 34167 & 182 & .0 .33 \\
\hline Philippines & 0.49 & 0.35 & 0.65 & 239 & 15646 & 200 & 53235 & 287 & .0 .26 \\
\hline Poland & 0.02 & 0.00 & 0.07 & 179 & 18550 & 1478 & 81223 & 179 & 0.41 \\
\hline Portugal & 0.26 & 0.04 & 0.47 & 124 & 10294 & 138 & 39018 & 159 & .0 .11 \\
\hline Qutary & 0.16 & 0.00 & 0.58 & 93 & 30174 & 12750 & 70517 & 105 & 0.79 \\
\hline Rusia & 0.27 & 0.01 & 0.47 & 141 & 133944 & 4192 & 531685 & 142 & .0 .70 \\
\hline Soudi Arabia & & & & 0 & 115085 & 24452 & 365849 & 201 & \\
\hline Slorkia & 0.12 & 0.04 & 0.23 & 57 & 625 & 143 & 1585 & 99 & 0.78 \\
\hline South Africa & 0.01 & 0.00 & 0.05 & 178 & 126440 & 46895 & 327795 & 178 & 0.00 \\
\hline Srituma & 0.65 & 0.35 & 0.76 & 98 & 1963 & 392 & 6087 & 253 & .0 .32 \\
\hline Taiman & 0.54 & 0.00 & 0.97 & 214 & 161100 & 2566 & 580189 & 287 & .0 .83 \\
\hline Thailand & 0.55 & 0.29 & 0.79 & 239 & 24572 & 207 & 104992 & 395 & 0.02 \\
\hline Turkey & 0.03 & 0.00 & 0.67 & 231 & 21834 & 377 & 78464 & 263 & 0.14 \\
\hline Emirgtes & 0.25 & 0.03 & 0,02 & 93 & 38642 & 14282 & 97465 & 105 & 0.81 \\
\hline Vevernela & 0.29 & 0.00 & 0.67 & 142 & 3235 & 516 & 10714 & 268 & 0.03 \\
\hline Zimbobule & 0.74 & 0.58 & 0.89 & 97 & 1102 & 33 & 16629 & 392 & .0 .03 \\
\hline
\end{tabular}

Source: Authors' own compilation

This table reports summary statistics (mean, minimum, maximum, number of observations as well as the correlations) for the intensity of capital controls and the global market capitalization (in millions \$) on regional and country level. Correlations that are statistically significant at 5\% are reported in bold font. The monthly values of the intensity of capital controls are computed from market capitalization data available for the investable and global markets. The data coverage for the intensity of capital controls varies by countries and group of countries. The longest time series covers the period December 1975 to October 2008 (395 observations) and the shortest starts in February 1997 and ends in October 2001 (57 observations).

Table 3 reports descriptive statistics separately for the markets size of developed (i.e. OECD member states) and emerging countries ${ }^{7}$. Several trends are apparent. The 34 developed markets combined account for more than $90 \%$ of the world market capitalization (on average), but their weight has decreased by almost $16 \%$ (from $98 \%$ to $82 \%$ ) over the period. By contrast, the emerging markets become increasingly relevant, with composite market size increasing over the period from

${ }^{7}$ For the emerging countries statistics, both Datastream and EMDB sources of data are used.
${ }^{6}$ Throughout the remainder of the paper, the term size refers to the size of market capitalization. 
less than $1 \%$ to over $17 \%$. At the same time, the intensity of capital controls decreases for the composite index as well as averaged across countries.

Table 3: Size and Segmentation Variables Descriptive Statistics (DATASTREAM and EMDB Data)

\begin{tabular}{|c|c|c|c|}
\hline & $\begin{array}{c}\text { Size }(\%) \\
\text { Datastream Datata }\end{array}$ & $\begin{array}{c}\text { Size }(\%) \\
\text { EMDB Data }\end{array}$ & $\begin{array}{c}\text { Capital Controls } \\
\text { EMDB Data }\end{array}$ \\
\hline \multicolumn{4}{|l|}{ Dereloped Markets (OECD) } \\
\hline \multicolumn{4}{|l|}{ Composite Indax } \\
\hline Mean & 92.38 & & \\
\hline Range & 19.24 & & \\
\hline Change over Entre Peniod & .15 .84 & & \\
\hline Standard Deviation & 5.83 & & \\
\hline $\begin{array}{l}\text { Alisrages (per country) } \\
\text { Megan }\end{array}$ & 281 & \multicolumn{2}{|c|}{ Averages (per countron) } \\
\hline Range & 3.67 & & \\
\hline Change over Bntitre Penod & .0 .59 & & \\
\hline Standard Deviation & 0.91 & & \\
\hline \multicolumn{4}{|l|}{ Emerging.Varkets } \\
\hline \multicolumn{4}{|l|}{ Conposite Indax } \\
\hline Mean & 6.55 & 538 & 0.42 \\
\hline Range & 22.12 & 12.01 & 0.69 \\
\hline Change over Entitr Peniod & 16.42 & 8775 & .0 .58 \\
\hline Standard Deviation & 6.65 & 270 & 0.19 \\
\hline Conelation (Sizz, Capital Controls) & $\cdot 0.40$ & .0 .25 & \\
\hline \multicolumn{4}{|l|}{ Averages (per country) } \\
\hline Nean & 0.36 & 0.17 & 0.28 \\
\hline Range & 0.84 & 0.53 & 0.59 \\
\hline Change over Butire Period & 0.41 & 0.14 & .021 \\
\hline Standard Deviztion & 0.23 & 0.12 & 0.16 \\
\hline Conelation (Size, Cappital Controls) & 0.39 & 0.44 & \\
\hline (Courter conrelations are taksn in ab & & & \\
\hline
\end{tabular}

Source: Authors' own compilation

This table reports some descriptive statistics (mean, range, change over the entire period and standard deviations) for the size and segmentation variables: The size of the market capitalization relative to the world market size (in percentages) and the intensity of capital controls. The statistics are reported for composite indices of OECD states and emerging markets as well as for country averages for the respective groups.

\section{Empirical Results}

This section presents the main empirical evidence on the presence size effects, analyzed initially over time for individual countries and then aggregated, by constructing panels of developed and emerging countries to take into account the cross-section dimension along with the time variation in the data.

\section{Individual Size Effects}

A preliminary investigation of size effects is done at individual (country) level, by augmenting the I-CAPM relationship for each market index with a local factor, the size of market capitalization. Time series regressions of expected returns on the global factor, the world market index and a proxy for market size, are estimated in the following simple framework:

$$
r_{d_{t}}-r_{f_{t}}=\alpha+\beta\left(r_{w_{t}}-r_{f_{t}}\right)+\gamma \operatorname{Size}_{t-1}+\varepsilon_{t},
$$

Where $r_{d_{t}}$ are (monthly) returns on the domestic market index for each developed and emerging country in our dataset, $r_{w_{t}}$ are the returns on the world market index, $r_{f_{t}}$ is the risk-free rate and $\alpha$ and $\varepsilon_{t}$ are respectively the intercept and the error term. Size $e_{t-1}$ is proxied by the share of the country's market capitalization in the world market (in percentages).

The time series dimension allows us to test whether the inverse relationship between market size and expected returns holds within each market. At any point in time, market size can be interpreted as the demand of assets both from domestic and foreign investors in a given country. A negative relationship between market size and returns, shows that as the market size increases, expected returns decrease and the size premium for that market is eroded.

The effects of market size on expected returns over time are estimated using equation 2 , individually for all developed (OECD member states) and emerging countries in the sample using both databases available. Regressions based on the Datastream data presented in Table 4 show that size effects have the 'correct' (negative) sign for 59 out of 61 countries (the only exceptions being Estonia and Finland). The coefficients are statistically significant in 20 cases.

Table 4: Size Effects, Time Series Regressions (DATASTREAM Data)

\begin{tabular}{|c|c|c|c|c|}
\hline & 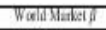 & Twallath & $\operatorname{six}$ & 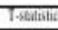 \\
\hline Argtalitili & $1 . \sigma^{p+1}$ & $(099)$ & $\sin$ & (F) \\
\hline Axistala & $1.0^{+* t}$ & (12.16) & -0.43 & $(-131)$ \\
\hline Awatin & $0.78^{6+4}$ & $(745)$ & .2 .6 & $(-10.56)$ \\
\hline Baltain & $0.19^{* t *}$ & (2.78) & $-1055.67^{* *}$ & $(-2.53)$ \\
\hline Belgan & $0.93^{+0 * *}$ & (1451) & .2 .8 & $(-135)$ \\
\hline Hlanal & $1.51^{t \omega t}$ & (1132) & -0.1 .66 & $(-1.26)$ \\
\hline Catadia & $0 . n^{t+t+t}$ & (15.65) & $-0.12^{*}$ & $(-1.78)$ \\
\hline Chilt & $0.7 v^{t+*}$ & (6.82) & $-6.04^{* *}$ & (-2.33) \\
\hline Chim & $0.50^{t+4 t}$ & (3.63) & -9.40 & $(-1.58)$ \\
\hline Colunksa & $0.7 v^{t+*}$ & (6.il) & -10.88 & $(-0.21)$ \\
\hline Cath Repubte & $0.2^{2+*}$ & (6.54) & .9 .16 & $(-0.72)$ \\
\hline Denmark & $0.84+t+t$ & (13.44) & . $1 . \mathrm{A}$ & $(-1.92)$ \\
\hline $\mathrm{Egpl}_{\mathrm{pl}}$ & $0.72^{t+*}$ & (499) & .8 .50 & $(-0.77)$ \\
\hline Elatus: & $0.87^{+6+t}$ & (4.18) & 23992 & (0.55) \\
\hline Fititial & $1.3160+6$ & (15:02) & 0.30 & (0.14) \\
\hline Fante & $1.14^{t * t *}$ & (21.95) & .0 .15 & $(-1.00)$ \\
\hline Getriay & $0.5^{t+0}$ & (16.88) & $-0.5 s^{* *}$ & $(-240)$ \\
\hline Gintest & $1.12^{\text {tet }}$ & (739) & -4.93 & $(-0.4)$ \\
\hline Hazary & $1.53^{t+6 t}$ & (11.60) & .18 .4 & $(-0.83)$ \\
\hline lectind & $1.1 .2 *$ & (199) & 21.39 & $(-0.31)$ \\
\hline lnsia & 1.1.1 & (7896) & -0.50 & $(-0.94)$ \\
\hline lnaburia & $1.11^{t+6 t}$ & (3.39) & $\mid .8 \mathrm{RI}$ & $(-0.70\}$ \\
\hline lelelunt & 1.1.10te & (1599) & .3 .56 & $(-1.97)$ \\
\hline linat & $0.6^{20+4}$ & (1698) & 3.10 & $(-0.37)$ \\
\hline lialy & $1.01^{+6 * t}$ & (15.37) & .0 .60 & $(-151)$ \\
\hline lanat & $0.32^{2+t}$ & (13.10) & -0.06 & $(-0.21)$ \\
\hline Jonial & $0.97^{t+4}$ & (294) & $.56 .55^{\circ}$ & $(-1.90)$ \\
\hline Kaxta & $1.27 \%$ & (10.40) & .139 & $(-1+A \mid)$ \\
\hline Kursall & $0.55^{* t+}$ & (4678) & $.22 .53^{\circ * *}$ & $(-2.32)$ \\
\hline Liucateary & $0.60^{2+*+1}$ & (799) & $.54,72^{2 * *}$ & (-3.38) \\
\hline Malinsal & $0.77^{40+*}$ & (8.15) & $-2,2^{*}$ & $(-1.34$ \\
\hline Mexiso & $1.11^{60+0}$ & (1354) & $\sin 0^{2}+4$ & $(-3.37)$ \\
\hline Mancico & $0.29^{t+*}$ & (277) & -6.74 & $(-1.26)$ \\
\hline The Konteliniti & 1.606te & (18.42) & 0.17 & $(-1.57)$ \\
\hline Nex Zelahs & $0.91^{+6 * t}$ & (1356) & .10 .16 & $(-1.80)$ \\
\hline Nigera & $0.51^{\text {tot }}$ & (283) & .27 .81 & (1.1.19) \\
\hline Newoug & $1.22^{t+6}$ & (13.1.15) & 0.11 & $(-1.07)$ \\
\hline Oman & $0.53^{t+4}$ & (50,8) & .130 .50 & $(-1.63)$ \\
\hline Pilitath & $0.44^{t+4 t}$ & (3.45) & -37.56 & $(-1,154)$ \\
\hline Peru & $0.51^{t+6 t}$ & (466) & 3.28 & $(-0.61)$ \\
\hline Phippinas & $0.94+4$ & (6.95) & 3.67 & $(-1.62)$ \\
\hline Polatal & $1.43^{t+6}$ & (1259) & -1.46 & (-0.1.12) \\
\hline Proway & $0.91^{406}$ & (1292) & 4.72 & {$[-0.14)$} \\
\hline Qulat & $0.83^{20 *}$ & (429) & $.27 .03^{* *}$ & $(-2.24)$ \\
\hline Rusia & $1.63^{3+6}$ & (850) & $-2.01^{*}$ & $(-1.44)$ \\
\hline Sund Anda & $0.50^{40 *}$ & (328) & .3 .76 & $(-0.82)$ \\
\hline Slondia & $0.13^{+6 *}$ & (296) & $.951 .70+4$ & $(-2.30)$ \\
\hline Sbraia & $0.640+4$ & (502) & $.11154,32$ & $(-0.22)$ \\
\hline Soulth Afriä & 1. . $^{2+* t}$ & (13.14) & $-2.22^{2+4}$ & $(-262)$ \\
\hline Spit & 1.1.15** & $(20.72)$ & 0.64 & $(-1.28)$ \\
\hline Sin Latka & $0.41^{3 t+t}$ & (3.1.5) & .26 .4 & (-0.5) \\
\hline Sweten & $1.23^{20 *}$ & (17.16) & .0 .19 & $(-1.56)$ \\
\hline Switazland & $0.5^{7+4+4}$ & (2609) & .0 .12 & $(-135)$ \\
\hline Tuikan & $0.3 s^{5+\infty}$ & (760) & $-7.65^{* *}$ & $(-2.55)$ \\
\hline Thuilual & $1.20^{0 * 6}$ & (1648) & $.5 .37 \%$ & $(-24)$ \\
\hline Tuklty & $1.33^{0+6}$ & (6.19) & $14.98+40$ & (-305) \\
\hline United Anab Eminiter & $0.50^{t+4}$ & $(365)$ & $.23 .84 * 4$ & $(-3.59)$ \\
\hline Vtukd Kingutan & $1.11^{* * t}$ & (1401) & $-0.61^{*}$ & $(-1.83)$ \\
\hline Vtrikd Sultes & $0.91^{2+t+}$ & (3.A1) & $-0.020^{* 4}$ & $(-2.34)$ \\
\hline & $0.57^{704}$ & (3.32) & .58 .90 & $(-1.86)$ \\
\hline Zimithumint & & $(-0.21)$ & $.958 .16^{\circ}$ & \\
\hline
\end{tabular}

Source: Authors' own compilation 
This table reports world market betas and the country size effects based on the regression of domestic (monthly) excess returns on the (excess) returns on the world market index and a proxy of market size. Size is proxied by the share of a country's market capitalization in the world market (in percentages). Statistical inference is based on Newey-West standard errors and significance is denoted by $* * *$ (at $1 \%$ ), ** (at $5 \%$ ) and * (at 10\%).

Table 5 repeats the estimation for the EMDB database, which allows for size effects to be investigated not only for global indices, but also for the submarkets of investable indices (assets available to foreign investors) and non-investable indices (assets available only to domestic investors). The sign and statistical significance of country size effects are reported for each emerging market in the sample as well as for 7 composite indices. Most countries and groups of countries exhibit negative size effects: 34 (respectively 29) countries out of 35 for investable (non-investable) indices as well as 37 out of 38 for global indices. The effects are statistically significant in many cases: 12 for the investable indices and 10 (19) for returns on non-investable (global) indices. These results suggest that the cost of capital tends to increase when markets are smaller or less developed. Among the regional return indices, the relationship between market size and expected returns is predominantly negative, the few exceptions being highly insignificant statistically. The Composite (All Countries) Index as well as the indices for Latin America, Asia and Europe produce consistently negative size effects.

Table 5: Size Effects, Time Series Regressions (EMDB Data)

\begin{tabular}{|c|c|c|c|c|c|c|}
\hline & \multicolumn{2}{|c|}{ EIDB Global Indices } & \multicolumn{2}{|c|}{ EMDB Inrestable Indices } & \multicolumn{2}{|c|}{ EMDB Non-Inretable Indices } \\
\hline & WMat (T-tatit) & Sizz (T-stat) & TWMat (T-stat) & Size (T-stat) & WM.Mt (T-stat) & Size (T-stat) \\
\hline Composite & $0.87+1+1.79)$ & $-0.15(-1.12)$ & $114^{+4+1}(16.64)$ & $-0.16+1+(-1.97)$ & $0.658+1+1.76)$ & $-0.56(-1.46)$ \\
\hline Latin Amer. & $1.09^{+1+t}(7.56)$ & $-1.30(-1.61)$ & $1.19^{t+1+1}(11.38)$ & $-2.42^{2+1+}(-4.15)$ & $1.00^{+3+1}(7.48)$ & $-2.36(-1.04)$ \\
\hline Agia & $0.85^{+t+1}+(8.18)$ & $-0.15^{*}(-1.69)$ & $1.16^{t+1+}(16.99)$ & $-0.10(-0.69)$ & $0.82+x+7.72)$ & $-0.80 *(-1.84)$ \\
\hline Eur. Nid Aff. & $1.01^{1+3+(8.45)}$ & $-0.10(-0.20)$ & $1.05^{5+1+1}(10.69)^{\prime}$ & $-0.72(-0.093)$ & $0.44^{+*}(2.01)$ & $1.53(0.59)^{\prime}$ \\
\hline Exope & $1.16^{6+1+(10.71)}$ & $3.78+7(-2.13)$ & $1.99^{4+t+}(15.73)$ & $-3.42^{+5+1}(-2.73)$ & $1.60^{+3+1}(6.97)$ & $-0.89(-0.07)$ \\
\hline East Eur. & $1.61^{1+x}(8.19)^{\prime}$ & $-1.10(-0.55)$ & $1.56^{t+1+}(12.09)$ & $-234(-1.45)$ & $1.61^{1+1+(6.31)}$ & $4.46(0.37)$ \\
\hline Maid Af. & $0.68+4+4(4.82)$ & $0.30(0.25)^{\prime}$ & $1.05^{5+t+}(15.16)$ & $-1.87(-1.32)$ & $0.13(0.76)$ & $0.62(0.25)$ \\
\hline Argentina & $0.60^{\text {tht }}(2.02)$ & $-37.08^{2+1+1}(-263)$ & $0.69+7(2.43)$ & $-20.18(-1.62)$ & $0.53(1.09)$ & $-11.58(-0.04)$ \\
\hline Bahrain & $0.42^{2+1+(4.59)}$ & $-209.100^{*}(-1.90)$ & $0.45^{+3+1}(3.99)$ & $.35 .1 .14 *(-1.81)$ & $0.33(0.93)$ & $.167 .46(-0.20)$ \\
\hline Brail & $1.04+3+(5.42)$ & $-5.27+27+(-2.73)$ & $1.57^{n+1}(1.1 .34)$ & $-3.77^{1++}(-2.88)$ & $1.55^{+t+1}(7.42)$ & $-13.32^{*}(-1.60)$ \\
\hline Chile & $0.3^{3+1+1}(3.57)$ & $-11.41^{ \pm *}(-2.29)$ & $0.7^{7+1+1}(6.90)$ & $-21.80^{+3+1+(-3.70)}$ & $0.50^{*+1+(3.24)}$ & $0.58(0.12)$ \\
\hline Ching & $0.63^{3+1}(3.52)$ & $-1.02(-0.80)$ & $1.12^{2+1+(9.49)}$ & $0.09(0.14)$ & $0.32 *(1.76)$ & $-5.35 \%+(-2.06)$ \\
\hline Colombia & $0.56^{* t+1}(4.98)^{\circ}$ & $-19.56(-1.32)$ & $0.10^{*}(1.87)^{\prime}$ & $-48.36(-1.14)$ & $0.07(0.38)^{\prime}$ & $352.85(1.42)^{\prime}$ \\
\hline Czech Rep. & $0.88+1+4(4.48)$ & $-49.00^{*}(-1.87)$ & $0.77^{+1+1}(2.87)$ & $-194.42^{+3+1}(-2.80)$ & $0.03(0.12)$ & $-43.19(-0.97)$ \\
\hline Egpt & $0.60^{* t+1}(3.51)$ & $.39 .68(-1.12)$ & $0.85^{2+t+(5.31)}$ & $44.27(-1.38)$ & $0.52^{+*}(2.34)$ & $-278.00^{1+7}(-2.17)$ \\
\hline Grece & $0.53^{3+1}(4.05)$ & $-11.71(-1.59)$ & $0.62^{2+6+(3.28)}$ & $.35 .77^{1+}(-2.52)$ & $0.37(1.63)$ & $-320.33^{1+*}(-2.17)$ \\
\hline Himgary & $1.46^{+1+1}(7.56)$ & $-24.77(-0.67)$ & $1.6^{7+4+}(10.86)$ & $.15 .38(-0.45)^{\prime}$ & $1.10^{+x+1}(6.02)$ & $-1298.12+4+(-2.00)$ \\
\hline India & $0.41^{1+1+(2.83)}$ & $-3.73(-1.61)$ & $1.00^{+3+1}(7.32)$ & $-0.49(-0.32)^{\prime}$ & $0.93^{+1+1}(5.11)$ & $-15.89+4+(-3.311)$ \\
\hline Iroponsia & $1.20^{+2+x}(5.16)$ & $-18.77^{1+1}(-2.19)$ & $1.32^{+4+1}(7.03)$ & $.1175^{*}(-1.84)$ & $1.29^{+1+1}(4.79)$ & $.14 .33(-0.88)$ \\
\hline Inrael & $0.80^{\text {tht }}(8.05)$ & $-10.68(-1.02)^{\prime}$ & $0.61^{1+1+(6.82)}$ & $-8.28(-1.39)^{\prime}$ & $1.32^{2++}(7.11)$ & $-1099.01+x+(-2.46)$ \\
\hline Jordan & $0.25+13+(3.17)$ & $\cdot 18.60(-1.08)$ & $0.24^{* *}(2.21)$ & $-402.23^{+1}(-2.02)$ & $0.18^{t}(1.86)^{\prime}$ & $.119 .73(-1.24)$ \\
\hline Korea & $0.99^{4+1}(7.57)$ & $-2.04+1+(-1.97)$ & $1.43^{+1+t+1}(1.2 .25)$ & $-0.01(-0.01)$ & $1.42^{2+1+(8.38)}$ & $-2.29(-1.63)$ \\
\hline Kumat & $0.67^{7+1+(5.36)}$ & $-11.10(-0.96)$ & $0.66^{t+1+1}(5.27)$ & $.20 .01(-1.26)$ & $0.60^{+3+1}(3.14)$ & $.21 .65(-0.35)$ \\
\hline Melyyjia & $0.88+4+6.55)$ & $-1.86(-1.49)$ & $0.88+\pi+(8.68)$ & $-3.11^{+*+(-1.94)}$ & $0.89+\operatorname{trt}(6.59)$ & $-2.42(-0.38)$ \\
\hline Merico & $1.01^{+1+t}(6.00)$ & $-4.37^{*}(-1.82)$ & $1.13^{*+1+(11.96)}$ & $-8.78^{+3+1}(-2.68)$ & $0.81^{1+1+}(3.55)$ & $.14 .90(-0.96)$ \\
\hline Marocco & $0.24(1.68)$ & $-48.45(-1.25)$ & $0.28^{8+1}+(2.61)$ & $.34 .08(-1.33)^{\prime}$ & $0.23(1.55)$ & $-13.37(-0.08)$ \\
\hline Nigeria & $0.36^{+1}(2.50)$ & $-118.02^{2+1+(-271)}$ & & & & \\
\hline Oman & $0.4^{4+1}(3.32)$ & $-192.16(-1.10)$ & $0.61^{+k+}(4.79)$ & $-293.59(-0.98)$ & $0.50 * 5(2.20)$ & $.744 .55(-0.83)$ \\
\hline Pakistan & $0.31^{1+\ldots+(3.68)}$ & $-63.82^{2+1}(-2.30)$ & & & & \\
\hline Pen & $0.83^{3+r}(4.18)$ & $-80.64^{4+1+}(-2.76)$ & $0.87+1+6.04)$ & -62.94 t*t $(-3.14)$ & $0.56^{*+1+}(2.71)$ & $-29.42(-0.08)$ \\
\hline Pulilippines & $0.04^{+1+1}(6.37)$ & $-18.60^{+1+1}(-2.28)$ & $0.04+4+(7.88)$ & $-19.62^{2+}(-2.08)$ & $1.01^{1+3+(5.34)}$ & $.24 .82 \pm(-1.93)$ \\
\hline Poland & $\left.1.3^{3+1+(8.39}\right)$ & $3.36(0.29)$ & $1.55^{n+1+(12.56)}$ & $-0.53(-0.71)$ & $1.27^{7+1+1}(6.54)$ & $.286 .88(-1.111)$ \\
\hline Portugal & $1.03+3+6.96)$ & $-65.10^{+1+}(-2.29)$ & $0.98+18.787)$ & $-9.70(-0.47)$ & $0.92^{2+1+}(7.92)$ & $.72 .94(-1.29)^{\prime}$ \\
\hline Qatar & $0.86^{t+1+(3.83)}$ & $.30 .24(-0.96)^{\prime}$ & $0.86+t+(4.65)$ & $-197.51^{+*+*}(3.68)$ & $0.98+1+3.60)$ & $68.78(1.45)$ \\
\hline Russia & $191^{1+x+(5.57)}$ & $-4.04(-1.05)$ & $1.78+1+(7.75)$ & $-5.12(-1.58)$ & $1.81+1+4+499)$ & $0.39(0.03)$ \\
\hline Saudi Arabia & $0.51^{+3+1}(3.30)$ & $-3.87(-0.84)$ & & & & \\
\hline Slorakia & $0.03(0.13)$ & $-340.37(-1.20)$ & $0.03(0.12)$ & $-973.44^{4 *}(-1.94)$ & $-0.11(-0.57)$ & $-6139.63 \% 40(-3.45)$ \\
\hline Soth Afica & $1.0^{\text {tht }}(8.35)$ & $-1.56(-1.00)$ & $1.18^{+1+t}(12.19)$ & $-2.21(-1.42)$ & $0.97+4+(3.20)$ & $16.52(0.29)$ \\
\hline SniLanka & $0.47^{7+1+(3.47)}$ & $.234 .04(-1.47)$ & $0.78+\pi+(3.26)$ & $-676.53(-1.57)$ & $0.38+5(2.05)$ & $.121 .95(-0.40)$ \\
\hline Tairizn & $0.92^{2+1}(5.75)$ & $47^{2+}(-2.30)$ & $1.05^{5+1+(13.23)}$ & $-0.28(-0.28)^{\prime}$ & $1.00^{+1+1}+(0.12)$ & $-0.81(-0.55)$ \\
\hline Thailand & $0.92^{2+x}(5.79)$ & $-3.67+(-1.70)$ & $1.20^{+t+1}(9.99)$ & $-13.15^{++1+(-2.10)}$ & $1.34^{+4+1}(7.44)$ & $.5 .93^{\circ}(-1.60)$ \\
\hline Turkey & $1.28^{8+1+(5.04)}$ & $-83.39+1+1-279)$ & $1.47+3 \times(7.37)$ & $-100.55^{t+1+1}(-4.50)$ & $3.14^{4+3}(3.40)$ & $1639.79+4 \times(4.15)$ \\
\hline United Arab & $0.94^{4+2+}(7.63)$ & $.30 .81 \div(-1.88)^{\prime}$ & $1.11^{*+1+(7.59)}$ & $-49.37(-1.31)$ & $0.03(0.03)$ & $21.18(0.38)$ \\
\hline & & & & & & \\
\hline & & & & $-352.62^{*+1+}(-2.98)$ & & \\
\hline Zimbabure & $-0.68(-0.82)$ & $.358 .26^{*}(-1.92)$ & $0.59 *(1.77)$ & $.2147 .28(-1.57)$ & $0.52^{*}(1.69)$ & $.26723(-0.06)$ \\
\hline
\end{tabular}

Source: Authors' own compilation
This table reports world market betas and the country size effects based on the regression of domestic (monthly) excess returns on the (excess) returns on the world market index and a proxy of market size. Size is proxied by the share of the country's market capitalization in the world market (in percentages). Statistical inference is based on Newey-West standard errors and significance is denoted by $* * *$ (at $1 \%$ ), ** (at $5 \%$ ) and $*$ (at $10 \%)$.

These findings suggest that size effects are not particular to one type of countries, but belong to a pattern common to many emerging as well as developed countries. Although developed markets are better integrated in the world market than emerging markets, the process is not complete as various transaction costs and informational asymmetries still in place may actually hinder cross-border equity trade.

Aggregate Size Effects in Emerging and Developed Markets

Market size effects may be more relevant in crosscountry comparisons, especially when interpreted as evidence of market segmentation, considering that more integrated countries have better access to the available foreign capital. In order to take advantage of both the cross-sectional and time-series dimension of the data, panel data models, allowing for country fixed effects, become the main regression framework.

The basic panel model involves regressing the domestic (monthly) excess returns on the (excess) returns on the world market index and a proxy of size:

$$
r_{d_{i, t}}-r_{f_{t}}=\alpha_{i}+\beta\left(r_{w_{t}}-r_{f_{t}}\right)+\gamma \operatorname{Size}_{i, t-1}+\varepsilon_{i, t} \text {, }
$$

Where $\alpha_{i}$ and $\varepsilon_{i, t}$ are respectively the intercept and the error term. Size $e_{i, t-1}$ is proxied by the share of the country $i$ 's market capitalization in the world market (in percentages). The panel data estimations of the basic model, equation (3), impose that the size effects are the same for every country in the panel. The estimate of the coefficient of the size effect is therefore interpreted as an average effect for the group of countries in the panel.

Table 6 (models -1- to -6-) provides panel data estimates of size effects for the full sample of countries in the Datastream data (developed and emerging countries taken together). Size effects are statistically significant (model -1-) and persist when a measure of segmentation, the intensity of capital controls is introduced (model -2-)8. While size effects are statistically significant for the entire set of countries, interacting the size proxy with a dummy variable for emerging markets (models -3- and -4-, the latter controlling for segmentation as well), shows that the results are stronger for the emerging markets. Size effects are found also in the group formed only by developed markets (OECD member states) when investigated separately (models -5- and -6-), suggesting that size effects are not an emerging markets phenomenon.

${ }^{8}$ For the purpose of these estimations, Q is set to 0 for the OECD member states that are not covered in the EMDB, based on the assumption that these countries do not enforce any restrictions on foreign ownership of equities. 
Repeating the analysis on detailed data from EMDB (Table 6, models -7- to -12-) shows that size effects are present for all three indices (for returns on investable, non-investable and global assets) and are significant. This database also allows also to check the robustness of size effects to the inclusion of a direct segmentation proxy, given by the intensity of capital controls. De Jong and De Roon (2005) find that expected returns are higher in countries that have a higher intensity of capital controls. The basic model extended to include the segmentation proxy becomes:

$$
\begin{gathered}
r_{d_{i, t}}-r_{f_{t}}=\alpha_{i}+\beta\left(r_{w_{t}}-r_{f_{t}}\right)+\gamma \widetilde{\operatorname{Size}}_{i, t-1}+\delta Q_{i, t-1}+ \\
\varepsilon_{i, t},(4)
\end{gathered}
$$

Where $\alpha_{i}$ and $\varepsilon_{i, t}$ are respectively the intercept and the error term. $Q_{i, t-1}$ is the intensity of capital controls and $\widetilde{S i z e}_{i, t-1}$ is proxied by the residual from regressing the original size variable - the share of a country's market capitalization in the world market (in percentages) - on the remaining explanatory variables ${ }^{9}$. Size effects are significant without exception across all 12 variations of the model presented in Table 6 and unaltered by the introduction the intensity of capital controls (highly insignificant in all 6 models where present).

Table 6: Size Effects, Panel Data Regressions

\begin{tabular}{|c|c|c|c|c|c|c|c|c|}
\hline Group & $\begin{array}{l}\text { No. countries } \\
\text { No. obs. }\end{array}$ & Model & $\begin{array}{l}\text { WMkt } \\
\text { (T-stat) }\end{array}$ & $\begin{array}{c}\text { Size } \\
(\mathrm{T}-\mathrm{s} \text { tat })\end{array}$ & $\begin{array}{l}\text { Size } \times 0 \\
(1-\text { stat })\end{array}$ & $\begin{array}{l}\text { Size } \\
\text { (T-stat) }\end{array}$ & $\begin{array}{c}Q \\
(1-\text { stat })\end{array}$ & $\operatorname{Adj} \cdot R^{2}$ \\
\hline Datastream & 61 & -1. & $0.92^{+* i *}$ & $-0.04^{+*+1+}$ & & & & 0.18 \\
\hline \multirow[t]{7}{*}{ All } & 18774 & & $(40.01)$ & $(-3.12)$ & & & & \\
\hline & 58 & -2. & $0.99^{+i+}$ & & & $-0.03^{* *}$ & 0.10 & 0.29 \\
\hline & 15509 & & (52.82) & & & $(-252)$ & (0.12) & \\
\hline & 61 & .3. & $0.92^{2+i+}$ & $-0.04^{++*+1}$ & $-0.97^{+*+*}$ & & & 0.18 \\
\hline & 18774 & & (39.93) & $(-3.04)$ & $(-2.82)$ & & & \\
\hline & 58 & 4 & $0.99^{+i+}$ & & $-1.25^{+* k}$ & $-0.02^{* *}$ & -0.13 & 0.29 \\
\hline & 15564 & & (52.98) & & $(-299)$ & $(-213)$ & $(-0.17)$ & \\
\hline Datastream & 34 & .5 . & $1.04^{* i *}$ & $-0.02^{* *}$ & & & & 0.39 \\
\hline \multirow[t]{3}{*}{$O E C D$} & 11494 & & (35.46) & $(-2.15)$ & & & & \\
\hline & 33 & -6 & $1.04^{*+1+}$ & & & $-0.02^{* *}$ & .229 & 0.40 \\
\hline & 11414 & & (53.36) & & & $(-207)$ & $(-0.91)$ & \\
\hline EMDB & 38 & .7. & $0.7^{* \text { *iz }}$ & $-3.95^{\text {tik }}$ & & & & 0.06 \\
\hline Global & 9368 & & (15.07) & $(-5.87)$ & & & & \\
\hline \multirow[t]{2}{*}{ Indices } & 36 & 8 & $0.91^{+*+*}$ & & & $-4.23^{+ \text {+k+ }}$ & 0.60 & 0.12 \\
\hline & 6117 & & (21.74) & & & $(-4.63)$ & (0.54) & \\
\hline EMDB & 35 & 9 . & $1.00^{+i+1}$ & $-1.82^{*+*+1}$ & & & & 0.17 \\
\hline Imestable & 7181 & & (26.79) & $(-3.94)$ & & & & \\
\hline \multirow[t]{2}{*}{ Indices } & 35 & $-10-$ & $1.01^{t+i}$ & & & $-3.14^{*+*}$ & 0.59 & 0.16 \\
\hline & 6089 & & (24.15) & & & $(-3.83)$ & (0.61) & \\
\hline EMDB & 35 & $-11-$ & $0.82^{2+1+}$ & $-2.61^{* *}$ & & & & 0.05 \\
\hline Non- & 4923 & & $(13.00)$ & $(-250)$ & & & & \\
\hline Inestable & 35 & -12 & $0.81^{*+*}$ & & & $-4.85^{\text {tik }}$ & 1.18 & 0.05 \\
\hline Inaices & 4891 & & (1296) & & & $(-3.53)$ & $(0.82)$ & \\
\hline
\end{tabular}
(DATASTREAM Data)

Source: Authors' own compilation

This table reports the results of fixed effects panel regressions of domestic (monthly) excess returns on the (excess) returns on the world market index and a proxy for market size. When $Q$, the intensity of capital controls enters the regression, $\overline{\text { SIze }}$ is proxied by the residual from regressing the original size variable on the remaining explanatory variables, to avoid multicollinearity issues. For models 1 to $6, Q$ is set to 0 for all the OECD member states that are not covered in

${ }^{9}$ As size and segmentation are often highly correlated, the orthogonalized measure of size, $\widetilde{\text { Size }}$, is used throughout the paper, when the intensity of capital controls is included as an explanatory variable. the EMDB. For the equations that include both developed and emerging countries, the Size variable is interacted with a dummy for emerging markets $D$. Statistical inference is based on Newey-West standard errors and significance is denoted by $* * *$ (at $1 \%$ ), ** (at $5 \%$ ) and $*$ (at $10 \%)$.

So far, the empirical analysis uncovers three main patterns. First, market size effects appear to be a ubiquitous phenomenon. Secondly, they are stronger in emerging than developed markets and lastly, size effects are more relevant than the intensity of capital controls as a factor in explaining asset returns in these markets.

\section{Robustness Checks}

The previous analysis presents evidence of market size effects that are robust to including a proxy of market segmentation, the intensity of capital controls. Moreover, market size effects prove stronger and more persistent than segmentation effects. Next, a number of robustness checks contribute to establishing the validity of this result.

Since firm level size effects are known to be elusive over time (see Brown et al., 1983, for instance), the basic and extended models (equations 3 and 4), are reestimated for 5-year subperiods. Table 7 reports the panel data estimates of size effects for all the countries (using the Datastream data) for 5-year subperiods. Size effects maintain size and statistical significance through all the subperiods and in the presence of segmentation effects. The pattern persists in the panel containing all countries as well as in the subsample restricted to developed countries (OECD member states) and in the presence of the intensity of capital controls.

Table 7: Size Effects, Panel Data Regressions, 5-year

\begin{tabular}{|c|c|c|c|c|c|c|c|c|}
\hline Period & $1975-1979$ & 1980-1984 & 1985-1989 & 1990-1994 & $1995-1999$ & $2000-2004$ & $2005-2009$ & 2010-2014 \\
\hline \multicolumn{9}{|c|}{ DATASTREAM All Countries } \\
\hline No. countries & 16 & 18 & 29 & 45 & 53 & 56 & 60 & 60 \\
\hline No.obs. & 948 & 1054 & 1316 & 2081 & 2976 & 3216 & 3480 & 3358 \\
\hline Size & $-0.13^{*}$ & $-0.52^{* i *}$ & $-0.11^{* * i}$ & $-0.55^{\text {tim }}$ & $-0.21^{* i *}$ & $-0.91^{* * *}$ & $-0.54^{* *}$ & $-0.85^{+* i+}$ \\
\hline (I-stat) & $(-1.73)$ & $(-3.96)$ & $(-2.80)$ & $(-526)$ & $(-2.85)$ & $(-3.21)$ & $(-2.44)$ & $(-2.93)$ \\
\hline$A d j . R^{2}$ & 0.27 & 0.28 & 0.22 & 0.13 & 0.15 & 0.19 & 0.16 & 0.38 \\
\hline No countries & & & 25 & 44 & 50 & 50 & 50 & 38 \\
\hline No.obs. & & & 1084 & 1914 & 2854 & 2815 & 2668 & 2094 \\
\hline Size & & & $-0.10^{+* *}$ & $-0.42^{i * *}$ & $-0.20^{*+}$ & $-0.80^{*+i *}$ & $-0.54^{* *}$ & $-0.49^{ \pm+*}$ \\
\hline (I-stat) & & & $(-290)$ & $(-432)$ & $(-2.83)$ & $(-3.19)$ & $(-2.27)$ & $(-2.66)$ \\
\hline$Q$ & & & 19.38 & 6.78 & $-4.41^{*}$ & 1.86 & $7.31^{1+i+}$ & -5.06 \\
\hline (I-stat) & & & (0.87) & $(0.60)$ & $(-1.65)$ & $(0.52)$ & (295) & $(-139)$ \\
\hline Adj, $R^{2}$ & & & 0.28 & 0.13 & 0.17 & 0.27 & 0.57 & 0.53 \\
\hline \multicolumn{9}{|c|}{ DATASTREAM OECD Countries } \\
\hline No. countries & 14 & 16 & 20 & 24 & 28 & 29 & 30 & 34 \\
\hline No.obs. & 840 & 934 & 1043 & 1361 & 1609 & 1729 & 1781 & 1875 \\
\hline Size & $-0.13^{*}$ & $-0.50^{*+i}$ & $-0.10^{*+i *}$ & $-0.44^{* * *}$ & $-0.16^{* *}$ & $-0.67^{7 * i x}$ & $-0.27^{* i}$ & $-0.56^{\text {** }}$ \\
\hline (I-stat) & $(-1.79)$ & $(4.00)$ & $(-278)$ & $(-530)$ & $(-2.45)$ & $(-279)$ & $(-234)$ & $(-257)$ \\
\hline$A d j . R^{2}$ & 0.32 & 0.35 & 0.28 & 0.19 & 0.16 & 0.41 & 0.62 & 0.58 \\
\hline No. countries & & & 25 & 24 & 28 & 29 & 30 & \\
\hline No.obs. & & & 1084 & 1359 & 1609 & 1729 & 1780 & \\
\hline$\widehat{S i z e}$ & & & $-0.10^{\text {t+k }}$ & $-0.37^{+* *}$ & $-0.16^{* *}$ & $-0.62^{+* i}$ & $-0.29^{* *}$ & \\
\hline (I-stat) & & & $(-2.89)$ & $(-4.00)$ & $(-2.44)$ & $(-285)$ & $(-2.28)$ & \\
\hline$Q$ & & & 19.38 & 15.81 & $-15.13^{+*}$ & -3.75 & -24.86 & \\
\hline (T-stat) & & & $(0.87)$ & (1.01) & $(-2.73)$ & $(-0.24)$ & $(-137)$ & \\
\hline $\mathrm{Adj}, \mathrm{R}^{2}$ & & & 0.28 & 0.20 & 0.25 & 0.41 & 0.62 & \\
\hline
\end{tabular}
subperiods (DATASTREAM Data)

Source: Authors' own compilation

This table reports the results of fixed effects panel regressions of domestic (monthly) excess returns on the (excess) returns on the world market index and a proxy for market size. Size is proxied by the share of a country's market capitalization in the world market (in percentages). The sample is reduced to 5-year 
subperiods. Statistical inference is based on Newey-West standard errors and significance is denoted by $* * *$ (at $1 \%$ ), ** (at 5\%) and * (at $10 \%$ ).

Table 8 shows the panel data estimates of size effects for 5-year subperiods using the three indices available in the EMDB dataset: investable, noninvestable and global returns. For the global and investable indices, size effects fall out of statistical significance only for the earliest and latest sub periods (when data is most scarce). For the non-investable indices, the results are less robust, size effects being significant only in half of the subsamples.

Table 8: Size Effects, Panel Data Regressions, 5-year subperiods (EMDB Data)

\begin{tabular}{|c|c|c|c|c|c|c|c|c|}
\hline $\begin{array}{l}\text { Period } \\
\end{array}$ & $1975-1979$ & $1980-1984$ & $1985-1989$ & $1990-1994$ & $1995-1999$ & $2000-2004$ & $2005-2009$ & $2010-2014$ \\
\hline \multicolumn{9}{|c|}{ EMDB Global Indices } \\
\hline No. counties & 10 & 10 & 18 & 26 & 35 & 34 & 35 & 10 \\
\hline No. obs. & 455 & 600 & 1043 & 1231 & 1818 & 2006 & 1691 & 524 \\
\hline Size & .6 .27 & $-10.72^{* *}$ & $-5.01^{1+k}$ & $-8.55^{*+*}$ & $-6.23^{++3+}$ & $-14.62+2+1$ & $.3 .83^{+*+*}$ & $.33 .07 *$ \\
\hline (T-statt) & $(-1.37)$ & $(-2.03)$ & $(-2.31)$ & $(-4.51)$ & $(-2.51)$ & $(-3.61)$ & $(-3.19)$ & $(-1.82)$ \\
\hline & & & 0.01 & 0.04 & 0.13 & & 0.08 & $0.13^{2}$ \\
\hline No. counties & & & 11 & 26 & 31 & 30 & 27 & 5 \\
\hline No. obs. & & & 229 & 1057 & 1717 & 1545 & 1187 & 280 \\
\hline$\widetilde{\operatorname{SIZS}}$ & & & $-236.377 * i \hbar$ & $-7.69+* i$ & $-6.08^{+*+k}$ & $-12.95 * *+1$ & $-2.91^{i * i}$ & .14 .32 \\
\hline (T-stat) & & & $(-495)$ & $(-3.79)$ & $(-3.79)$ & $(-3.45)$ & $(-2.83)$ & $(-0.52)$ \\
\hline$Q$ & & & -12.19 & 6.60 & -2.22 & 3.80 & $9.11^{+* i t}$ & -1.68 \\
\hline (T-stat) & & & $(-0.88)$ & (1.08) & $(-0.76)$ & (1.05) & $(3.50)$ & $(-0.40)$ \\
\hline$A d d, R^{2}$ & & & 0.07 & 0.04 & 0.15 & 0.18 & 0.51 & 0.14 \\
\hline \multicolumn{9}{|c|}{ EMDB /mestablele naicess } \\
\hline No. counties & & & 11 & 25 & 30 & 29 & 26 & 26 \\
\hline No.obs. & & & 124 & 1027 & 1662 & 1477 & 1435 & 1456 \\
\hline Size & & & -457.69 & $-11.56^{*+* i+}$ & $-5.04^{* 3}$ & $-16.74^{* * *}$ & $-4.10^{* * * k}$ & $-7.65^{\mathrm{tit}}$ \\
\hline (T-stat) & & & $(-1.64)$ & $(-3.74)$ & $(-2.05)$ & $(-3.30)$ & $(-3.61)$ & $(-3.79)$ \\
\hline$A d j, R^{2}$ & & & 0.06 & 0.04 & 0.15 & 0.19 & 0.51 & 0.35 \\
\hline No. counties & & & 11 & 26 & 31 & 30 & 27 & 5 \\
\hline No. obs. & & & 114 & 1013 & 1657 & 1477 & 1222 & 606 \\
\hline$\tilde{\operatorname{sise}}$ & & & $-144,45^{+*+*}$ & $-8.77^{*+k}$ & $-6.66^{*+1 *}$ & $-13.31+\ldots+k$ & $-4.66^{i+k i}$ & $-9.21^{1+k i}$ \\
\hline (T-stat) & & & $(-2.19)$ & $(-2.99)$ & $(-2.70)$ & $(-2.77)$ & $(-3.36)$ & $(-3.78)$ \\
\hline Q & & & 8.55 & $16.05^{* t+}$ & 3.60 & $8.84+4$ & $8.91^{t+k}$ & 3.77 \\
\hline (T-stat) & & & $(0.58)$ & (2.38) & $(-1.28)$ & (2.32) & (3.45) & (0.74) \\
\hline$A d j, R^{2}$ & & & 0.01 & 0.04 & 0.16 & 0.19 & 0.53 & 0.32 \\
\hline \multicolumn{9}{|c|}{ ENDB Non-Inestable Indices } \\
\hline No. counties & & & 11 & 24 & 28 & 28 & 25 & 5 \\
\hline No.obs. & & & 124 & 998 & 1331 & 1287 & 978 & 204 \\
\hline Sise & & & $-20.79+\ldots+*$ & .7 .65 & $-8.41^{* * i}$ & $-42.59+* * *$ & .2 .79 & 276.82 \\
\hline (T-statt) & & & $(-4.58)$ & $(-0.96)$ & $(-3.04)$ & $(-4.27)$ & $(-1.00)$ & $(0.36)$ \\
\hline Adjj, $R^{2}$ & & & 0.03 & 0.02 & 0.08 & 0.12 & 0.40 & 0.00 \\
\hline No. counties & & & 11 & 24 & 28 & 28 & 25 & 5 \\
\hline No. obs. & & & 114 & 985 & 1327 & 1287 & 973 & 204 \\
\hline$\widetilde{S t E e}$ & & & -104.26 & .5 .62 & $-8.20^{* *}$ & $.39 .20^{+1+*}$ & $-7,46^{* * *+}$ & .226 .55 \\
\hline (T-stat) & & & $(-1.07)$ & $(-0.55)$ & $(-2.07)$ & $(-3.79)$ & $(-2.90)$ & $(-1.15)$ \\
\hline$Q$ & & & .24 .14 & 11.14 & .292 & $-9.87 \%$ & $12.36^{t+1+}$ & .70 .33 \\
\hline (T-stat) & & & $(-1.42)$ & (0.39) & $(-0.75)$ & $(-2.42)$ & $(2.67)$ & $(-1.18)$ \\
\hline$A d j \cdot R^{2}$ & & & 0.00 & 0.02 & 0.08 & 0.12 & 0.42 & 0.00 \\
\hline
\end{tabular}

Source: Authors' own compilation

This table reports the results of fixed effects panel regressions of domestic (monthly) excess returns on the (excess) returns on the world market index allowing for size effects. $Q$ is the intensity of capital controls and $\overline{S_{i z} e}$ is proxied by the residual from regressing the original size variable - the share of a country's market capitalization in the world market (in percentages) - on the remaining explanatory variables. The sample is reduced to 5-year subperiods. Statistical inference is based on Newey-West standard errors and significance is denoted by $* * *$ (at $1 \%$ ), $* *$ (at $5 \%$ ) and $*$ (at 10\%).

Next, the robustness of size effects is tested by including a set of control variables linked to global economic risks, similar to those proposed by Ferson and Harvey (1993). The following extended model results:

$r_{d_{i, t}}-r_{f_{t}}=\alpha_{i}+\beta\left(r_{w_{t}}-r_{f_{t}}\right)+\gamma \widetilde{S i z e}_{i, t-1}+\delta Q_{i, t-1}+$ $\varphi Q_{i, t-1} \times \widetilde{S i z e}_{i, t-1}+\theta^{\prime} X_{t}+\varepsilon_{i, t}$

Where $X_{t}$ includes six global risk variables: currency risk, $F X$, inflation risk, $G 7 I N F L$, interest rate risk, G7 IR, global credit risk, CR RISK, global output risk, G7 PROD and OIL\&GAS, the change in world prices for oil and gas as a measure of economic risk as well as a composite (country-specific) measure of political, financial and economic risk (obtained from the International Country Risk Guide).

Table 9 reports the panel data estimates of size effects (using Datastream and EMDB data, respectively) controlling for the additional risk factors (global or country specific) $)^{10}$. For the complete panel combining the developed and emerging markets, size effects have the expected negative sign but become marginally insignificant and appear small in economic terms. Statistical significance is maintained for the subsample of developed markets. For the emerging markets, size effects remain large and significant in the presence of the various risk variables (with the notable exception of the non-investable indices). Moreover, the interaction term shows that size effects seem to become stronger when capital controls drop. The effect is significant only for the assets that are available to foreign investors (investable indices).

Table 9: Size and Segmentation Effects, controlling for Global Risk Factors

\begin{tabular}{|c|c|c|c|c|c|c|c|c|c|}
\hline Group & No. countives & Model & WMKt & $\widetilde{\text { Size }}$ & $\widetilde{S}$ Sze $\times D$ & l & Stze $\times l$ & Composite & $\mathrm{Adj} \cdot \mathrm{R}^{2}$ \\
\hline & No.obs. & & (T-stat) & (I-stat) & (I-stat) & (T-stat) & (T.stat) & (T-stat) & \\
\hline \multicolumn{10}{|c|}{ DATASTREAM All Countries } \\
\hline & 58 & + & $0.83^{34 *}$ & .0 .02 & & .0 .40 & 1.06 & $-0.07^{444}$ & 0.30 \\
\hline & 13567 & & $(30.72)$ & $(-1.28)$ & & $(-0.53)$ & $(0.90)$ & $(-2.61)$ & \\
\hline & 58 & $\therefore$ & $0.88^{3+4 x}$ & 0.02 & $-1,43^{4+8}$ & -0.19 & $3.50^{2.4}$ & $-0.08^{454}$ & 0.30 \\
\hline & 13567 & & $(30.72)$ & $(-0.97)$ & $(-1.99)$ & $(-0.25)$ & (2.14) & $(-3.29)$ & \\
\hline \multicolumn{10}{|c|}{ DATASTREAM OECD Countries } \\
\hline & 33 & 3. & $0.90^{0 \pm 2}$ & $-0.03^{*}$ & & -1.13 & 9.28 & 0.01 & 0.40 \\
\hline & 9477 & & $(30.03)$ & $(-1.75)$ & & $(-0.37)$ & $(1.20)$ & $(0.22)$ & \\
\hline \multicolumn{10}{|c|}{ EMDB Global Indices } \\
\hline & 36 & 4 & $0.70^{* 4 * 4}$ & $-3.90 * 4 * 4$ & & .0 .83 & 2.62 & $-0.15^{448}$ & 0.14 \\
\hline & 6016 & & $(12.48)$ & $(-3.00)$ & & $(-0.74)$ & $(0.82)$ & $(-3.34)$ & \\
\hline \multicolumn{10}{|c|}{ EMDB Imestable Indices } \\
\hline & 35 & 5. & $0.79^{* * 4}$ & $-4.71^{1 * 4 k}$ & & 1.21 & $11.22^{\text {*24 }}$ & $-0.14^{4+4}$ & 0.17 \\
\hline & 6078 & & $(14.06)$ & $(-4.17)$ & & $(1.29)$ & $(2.94)$ & $(-3.35)$ & \\
\hline \multicolumn{10}{|c|}{ EMDB Non:Imestable Indices } \\
\hline & 35 & 6. & $0.59^{ \pm \pm 4}$ & .273 & & 1.31 & .1 .34 & $-0.13^{* *}$ & 0.06 \\
\hline & 4888 & & $(7.06)$ & $(-0.50)$ & & $(0.80)$ & $(-0.16)$ & $(-220)$ & \\
\hline
\end{tabular}

Source: Authors' own compilation

This table reports the results of fixed effects panel regressions of domestic (monthly) excess returns on the (excess) returns on the world market index and additional factors. $Q$ is the intensity of capital controls and $\widetilde{S i z e}$ is proxied by the residual from regressing the original size variable - the share of a country's market capitalization in the world market (in percentages) - on the remaining explanatory variables. All regressions include a set of six global risk variables, $X_{t}$ : the change in a price-adjusted index of the foreign exchange value of the dollar against a broad basket of currencies, the monthly change in the CPI of the G7 countries (Canada, France, Germany, Italy, Japan, UK and US), a weighted average of short term interest rates in G7 countries (with weights given by their

${ }^{10}$ All results are reported for the composite measure of risk. Using either the political, economic or financial elements of the composite measure does not alter the results. 
shares in the G7 GDP), the change in the difference between the 3-month Eurodollar rate and the 3-month US Treasury Bill yield, the change in the monthly PPI for the manufacturing sector and the change in the monthly world price index for oil and gas. For emerging markets, the set of variables is extended to include $Q$, the intensity of capital controls $(Q$ is set to 0 , for all the OECD member states that are not in covered in the EMDB and $\widetilde{\text { Size }}$ is interacted with a dummy variable for the emerging markets, $D$ ), an interaction term between and $Q$ and a country specific measure of Composite (economic, political and financial) risk. Statistical inference is based on Newey-West standard errors and significance is denoted by $* * *$ (at $1 \%$ ), ** (at $5 \%$ ) and * (at $10 \%$ ).

So far all estimated models have assumed constant world market betas. However, there is strong evidence that global (regional) market betas tend to increase with integration (see Bekaert and Harvey, 2000; Fratzscher, 2002; Baele, 2005, for instance). As a third robustness check, the world market betas are allowed to vary across countries and at the same as a function of segmentation (as in De Jong and De Roon, 2005) or a function of both segmentation and size. The increase in world markets betas has an opposite effect on expected returns. Whereas the cost of capital decreases as markets integrate, a larger exposure to the systemic (world market) risk is compensated through higher expected returns. The models to be estimated become

$$
\begin{aligned}
r_{d_{i, t}}-r_{f_{t}}= & \alpha_{i}+\left(\beta_{0, i}+\beta_{1} \times Q_{i, t-1}\right)\left(r_{w_{t}}-r_{f_{t}}\right)+ \\
\gamma \overline{S i z e}_{i, t-1}+ & \delta Q_{i, t-1}+\varphi Q_{i, t-1} \times \\
& \overline{S i z e}_{i, t-1}+\theta^{\prime} X_{t}+\varepsilon_{i, t},
\end{aligned}
$$

$$
\begin{array}{r}
r_{d_{i, t}}-r_{f_{t}}=\alpha_{i}+\left(\beta_{0, i}+\beta_{1} \times Q_{i, t-1}+\beta_{2} \times\right. \\
\left.\overline{S l z e}_{i, t-1}\right)\left(r_{w_{t}}-r_{f_{t}}\right)+\gamma \overline{\operatorname{Size}}_{i, t-1}+\delta Q_{i, t-1}+ \\
\varphi Q_{i, t-1} \times \overline{\operatorname{Size}}_{i, t-1}+\theta^{\prime} X_{t}+\varepsilon_{i, t},
\end{array}
$$

The results are presented in Table 10 for regressions using both sources of data (Datastream and EMDB). For the complete dataset, including both developed and emerging countries, size effects are manifest both directly (larger countries exhibiting lower expected returns) and indirectly, as larger markets (presumably more integrated) have higher world market betas (hence, higher exposure to systemic risk). The segmentation effect is manifest mainly indirectly through the interaction terms, showing that exposure to systemic risk increases as capital controls decline. This indirect effect is significant across both datasets, with the only exception of the subsample comprised by developed countries (for many of whom segmentation is low and even 0 by construction). The EMDB dataset allows uncovering a difference between the investable and noninvestable subsets of the markets. For the assets that are open to foreign investment, size has a strong direct effect, amplified by the segmentation effect (through the significant interaction term between the size proxy and the intensity of capital controls). There is also a counterintuitive negative indirect effect of size on World Market betas would suggest that the larger investable markets have lower exposure to systemic risk. The direct segmentation effect is significant and affects both expected returns (higher for segmented markets) and the World Market betas (lower for segmented markets) only for the subset of non-investable assets. This is also the only part of emerging markets where size effects lose statistical significance, providing further support to the conjecture that market size is intrinsically linked to market integration. The market size effect appears to manifest when preceded by financial liberalization (i.e. is stronger in the subset of the market that is open to foreign investors), suggesting that market development is induced by opening financial markets and might

\begin{tabular}{|c|c|c|c|c|c|c|c|c|}
\hline No. counties & Model & WMkt $\times$ Sise & WMkt $\times Q$ & Sise & Q & $\overline{S i t z e} \times 0$ & Composite & $A d j, R^{2}$ \\
\hline No. obs. & & (T-stat) & (T-stat) & $($ T-stat) & (T-statt) & (T-stat) & (T-stat) & \\
\hline \multicolumn{9}{|c|}{ DATASTREAMLAll Countriss } \\
\hline 58 & +1. & $0.03^{3+1+t}$ & & $-0.03^{2}$ & 0.65 & 0.36 & $-0.07^{7+t}$ & 0.32 \\
\hline 13546 & & (4.04) & & (-1.68) & $(-0.88)$ & (0.31) & $(-270)$ & \\
\hline 58 & -2. & & $-0.79^{+t+t}$ & -0.02 & .030 & 0.25 & $-0.07^{+t+t}$ & 0.32 \\
\hline 13346 & & & $(-423)$ & $(-1.11)$ & $(-0.40)$ & 0.21) & $(-265)$ & \\
\hline \multicolumn{9}{|c|}{ DATASTREAM OECD Coutries } \\
\hline $\begin{array}{c}58 \\
1354\end{array}$ & 3. & $\begin{array}{l}0.033^{++1+} \\
(4.02)\end{array}$ & $\begin{array}{l}-0.78^{+8+1+} \\
(420)\end{array}$ & $\begin{array}{l}0.0 .0^{7} \\
(-1.68)\end{array}$ & $\begin{array}{l}-0.30 \\
(-0.40)\end{array}$ & $\begin{array}{l}0.32 \\
(0.28)\end{array}$ & $\begin{array}{l}-0.00^{7+4+1} \\
(-264)\end{array}$ & 0.32 \\
\hline 33 & 4. & $0.03^{3+t+}$ & & $-0.04^{+* t}$ & .215 & 5.50 & 0.01 & 0.42 \\
\hline 9477 & & (3.90) & & $(-2.19)$ & (1.13) & (1.21) & $(0.42)$ & \\
\hline 33 & 5. & & .039 & $0.03^{\circ}$ & 0.40 & 5.19 & 0.01 & 0.42 \\
\hline 9477 & & & $(-0.74)$ & $(-1.67)$ & (0.14) & (1.13) & (0.42) & \\
\hline $\begin{array}{c}33 \\
9477\end{array}$ & -6 & $\begin{array}{l}0.0 .3+1+1 \\
(3.900)\end{array}$ & $\begin{array}{l}-0.38 \\
(-0.71)\end{array}$ & $\begin{array}{l}-0.04+t \\
(-2.19)\end{array}$ & $\begin{array}{l}-1.95 \\
(-0.999)\end{array}$ & $\begin{array}{l}5.17 \\
\text { (1.1.13) }\end{array}$ & $\begin{array}{l}0.01 \\
(0.42)\end{array}$ & 0.42 \\
\hline \multicolumn{9}{|c|}{ ENDB Global Indices } \\
\hline 36 & $\%$ & -0.14 & & $-3.13^{+*}$ & -1.17 & 0.06 & $-0.16^{5+t}$ & $\overline{0.16}$ \\
\hline 6010 & & $(-0.83)$ & & $(-2.43)$ & $(-1.06)$ & (0.02) & $(-3.82)$ & \\
\hline 36 & \&. & & $-0.03^{3+1+2}$ & $-2.90^{+t}$ & $\cdot 0.62$ & 0.13 & -0.16"trt & 0.16 \\
\hline 6010 & & & $(-4.46)$ & $(-2.26)$ & $(-0.54)$ & (0.04) & $(4.09)$ & \\
\hline $\begin{array}{l}36 \\
6010\end{array}$ & 4. & $\begin{array}{l}-0.20 \\
(-1.24)\end{array}$ & $\begin{array}{l}-0.95+t+1 \\
(4.522)\end{array}$ & $\begin{array}{l}-2997 \pi \\
(-2.31)\end{array}$ & $\begin{array}{c}.0 .60 \\
(-0.52)\end{array}$ & $\begin{array}{c}-0.07 \\
(-0.02)\end{array}$ & $\begin{array}{l}-0.10^{6+t+1} \\
(-3.88)\end{array}$ & 0.16 \\
\hline \multicolumn{9}{|c|}{ EMDB Investable Indices } \\
\hline $\begin{array}{l}35 \\
6062\end{array}$ & $=10$. & $\begin{array}{l}-0.41+* t \\
(-2.37)\end{array}$ & & 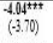 & $\begin{array}{l}-0.44 \\
(-0.47)\end{array}$ & $\begin{array}{l}8.385+* \\
(2.36)\end{array}$ & $\begin{array}{l}-0.13^{3+1+1} \\
(-3.20)\end{array}$ & 0.19 \\
\hline $\begin{array}{l}35 \\
6062\end{array}$ & .11 - & & $\begin{array}{l}-0.84+3+t \\
(-4.07)\end{array}$ & $\begin{array}{l}4.0 .2+3+8 \\
(-3.59)\end{array}$ & $\begin{array}{l}.003 \\
(-0.03)\end{array}$ & $\begin{array}{l}8.33+* \\
(2.32)\end{array}$ & $\begin{array}{l}-0.1 .1+3+t \\
(-3.41)\end{array}$ & 0.19 \\
\hline $\begin{array}{l}35 \\
6062\end{array}$ & 12. & $\begin{array}{l}-0.29+t+\pi \\
(-2.92)\end{array}$ & $\begin{array}{l}-0.89+1+t+2 \\
(-4.21)\end{array}$ & $\begin{array}{l}-39 g^{t+1} \\
(-3.63)\end{array}$ & $\begin{array}{c}-0.09 \\
(-0.09)\end{array}$ & $\begin{array}{l}799+4+ \\
(226)\end{array}$ & $\begin{array}{l}-0.11^{3+1+t} \\
(-3.14)^{\prime}\end{array}$ & 0.19 \\
\hline \multicolumn{9}{|c|}{ EMDB Non-Innestablele Indices } \\
\hline $\begin{array}{l}35 \\
4888\end{array}$ & $.13-$ & $\begin{array}{c}-0.09 \\
(-0.27)\end{array}$ & & $\begin{array}{l}-0.75 \\
(-0.13)\end{array}$ & $\begin{array}{l}2.41 \\
(1.64)\end{array}$ & $\begin{array}{l}6.51 \\
(0.73)\end{array}$ & $\begin{array}{l}-0.13^{+t+} \\
(-2.54)\end{array}$ & 0.08 \\
\hline $\begin{array}{l}35 \\
4888\end{array}$ & .14. & & $\begin{array}{l}-0.49^{*} \\
(-1.777)\end{array}$ & $\begin{array}{l}-0.34 \\
(-0.060)\end{array}$ & $\begin{array}{l}2.60^{*} \\
(1.81)\end{array}$ & $\begin{array}{r}-6.977 \\
(-0.78)\end{array}$ & $\begin{array}{l}-0.13 * * \\
(-2.522)\end{array}$ & 0.08 \\
\hline $\begin{array}{l}35 \\
4888\end{array}$ & -15. & $\begin{array}{c}-0.16 \\
(-0.47)\end{array}$ & $\begin{array}{l}-0.50^{*} \\
(-1.82)\end{array}$ & $\begin{array}{r}-0.44 \\
(-0.088)\end{array}$ & $\begin{array}{l}2.02^{*} \\
(1.81)\end{array}$ & $\begin{array}{l}.6 .92 \\
(-0.78)\end{array}$ & $\begin{array}{l}-0.13^{* *} \\
(-2.253)\end{array}$ & 0.08 \\
\hline
\end{tabular}
represent a further step in the process of financial market integration.

Table 10: Size and Segmentation Effects, with Country Specific and Time-Varying World Market Betas and Global Risk Factors

Source: Authors' own compilation

This table reports the results of fixed effects panel regressions of domestic (monthly) excess returns on the (excess) returns on the world market index and additional factors, with a first specification that allows the world market beta to vary over countries and over time and an alternative model allowing for the World Market beta to vary over countries and over time as a function of both the intensity of capital controls and size. $Q$ is the intensity of capital controls and $\widetilde{S z e}$ is proxied by the residual from regressing the original size variable - the share of a country's market capitalization in the world market (in percentages) - on $Q$ and the world market index. All regressions include a set of six global risk variables, $X_{t}$ : the change in a price-adjusted index of the foreign exchange value of the dollar against a broad basket of currencies, the monthly change in the CPI of the G7 countries (Canada, France, Germany, Italy, Japan, UK and US), a weighted average of short term interest rates in $\mathrm{G} 7$ countries (with weights given by their shares 
in the G7 GDP), the change in the difference between the 3-month Eurodollar rate and the 3-month US Treasury Bill yield, the change in the monthly PPI for the manufacturing sector and the change in the monthly world price index for oil and gas. The set of country specific variables extends with an interaction term between $\widetilde{\text { SIze }}$ and $Q$ and a measure of Composite (economic, political and financial) risk. Statistical inference is based on Newey-West standard errors and significance is denoted by $* * *$ (at $1 \%$ ), ** (at $5 \%$ ) and * (at 10\%). Overall, the results give evidence that market size affects expected returns both for developed and emerging markets. However, the effects appear strongest for emerging markets and especially for the part of emerging markets that is open to foreign investment.

\section{Economic Significance of Market Size Effects versus Segmentation Effects}

The previous sections established that expected returns, especially in emerging markets incorporate a size premium that appears to statistically dominate over segmentation effects. However, the relative importance of the two is ultimately decided by their economic significance. To obtain a measure of the economic impact of size and segmentation on expected returns, the observed changes in the variables of interest are combined with the estimation results obtained using the EMDB data for investable, non-investable and global returns. Partial size and segmentation effects are computed based on the estimated coefficients presented in Table 10.

$$
\begin{aligned}
& \Delta\left(r_{d}-r_{f}\right)=\left[\hat{\beta}_{2} \times \overline{\left(r_{w}-r_{f}\right)}+\hat{\gamma}+\hat{\varphi} \times \bar{Q}\right] \times \Delta \text { Size }, \\
& \Delta\left(r_{d}-r_{f}\right)=\left[\hat{\beta}_{1} \times \overline{\left(r_{w}-r_{f}\right)}+\hat{\delta}+\hat{\varphi} \times \overline{\text { Size }}\right] \times \Delta Q .
\end{aligned}
$$

The following observed data is substituted in the equations estimated for the emerging markets: the monthly expected (excess) return on the world market, $\overline{\left(r_{w}-r_{f}\right)}=0.44 \%$ (the sample average), the monthly average segmentation (the sample average), $\bar{Q}=0.28$. The average monthly changes in (composite) intensity of capital controls $\bar{Q}=-0.00242$ and in size, $\Delta$ Size being in turn equal to $0.0286 \%$ (for the Composite Investable Index), $0.0019 \%$ (for the Composite Non-Investable Index) and $0.0305 \%$ (for the Composite Global Index) give a sense of the scale of changes in the variables of interest. Thus calibrated, the annualized size effects for the returns add to $-0.63 \%$ for investable assets, $-0.05 \%$ for the non-investables and $-1.13 \%$ for the global index. In contrast, annual segmentation effects are entirely irrelevant in economic terms $(-0.03 \%,-0.06 \%$ and $0.03 \%$ for investable, non-investable and global returns).

\section{Conclusion}

This paper shows that market size is significantly related to expected returns and the relationship is especially relevant in emerging markets, where substantial size effects exist independently from (fading) segmentation effects previously reported in the literature. Small markets over persistently higher risk-adjusted expected returns. The results hold both within individual countries in the full sample as well as for subperiods. The presence and significance of size effects is robust to controls related to global economic risks as well as specific country risks. This evidence on market size effects is interpreted in the context of partial segmentation models, where a local factor, the market size commands a premium in terms of expected returns for smaller countries. The underlying mechanism could be that foreign capital responds to the decline in capital controls, driving market size up and lowering the cost of capital for companies.

\section{References}

Asness, C. S., J. M. Liew, and R. L. Stevens (1997). Parallels between the cross-sectional predictability of stock and country return. Journal of Portfolio Management 23, 79 - 87.

Baele, L. (2005). Volatility Spillover E_ects in European Equity Markets. Journal of Financial and Quantitative Analysis 40, 373-401.

Banz, R. W. (1981). The Relationship Between Return and Market Value of Common Stocks. Journal of Financial Economics 3, 3 - 18.

Barry, C. B., E. Goldreyer, L. Lockwood and M. Rodriguez (2001). Robustness of Size and Value Effects in Emerging Equity Markets, 1985-2000 Emerging Markets Review 3, 1 30.

Bekaert, G., C. B. Erb, C. R. Harvey and T. E. Viskanta (1997). The Cross-Sectional Determinants of Emerging Equity Market Returns Quantitative Investing of the Global Markets: Strategies, Tactics, and Advanced Analytical Techniques, chap. 11, pp. 221 - 272 (Glenlake Publishing).

Bekaert, G. and C. R. Harvey (2000). Foreign Speculators and Emerging Equity Markets. Journal of Finance 55, 565-613.

Brown, P., A.W. Kleidon, and T.A. Marsh (1983). New Evidence on the Nature of size-related anomalies in Stock Prices. Journal of Financial Economics 12, 33-56.

Cakici, N., Y. Tang and A. Yan (2016). Do the size, value, and momentum factors drive stock returns in emerging markets? Journal of International Money and Finance 69, 179 204.

De Jong, F. and F. A. De Roon (2005). Time Varying Market Integration and Expected Returns in Emerging Markets. Journal of Financial Economics 78, 583 - 613.

Edison, H. J. and F. E. Warnock (2003). A Simple Measure of The Intensity of Capital Controls. Journal of Empirical Finance 10, 81 - 103.

Erb, C. B., C.R. Harvey, and T.E. Viskanta (1996). Political Risk, Economic Risk and Financial Risk. Financial Analysts Journal 52, 28 - 46. 
Estrada, J. (2000). The cost of equity in emerging markets: A downside risk approach. Emerging Markets Quarterly 4, 19 - 30.

Fama, E. F. and K. R. French (1992). The Cross-Section of Expected Stock Returns. Journal of Finance $47,427-465$

Fama, E. F. and K. R. French (1993). "Common risk factors in the returns on stocks and bonds", Journal of Financial Economics 33, 3 - 56.

Fama, E. F. and K. R. French (1998). Value versus Growth: The International Evidence. Journal of Finance 53, 1975 - 1999.

Fama, E. F. and K. R. French (2008). Directed or Undirected? A New Index to Check for Directionality of Relations in Socio-Economic Networks. Journal of Finance 63, 1653 - 1678.

Fama, E. F. and K. R. French (2012). Size, Value, and Momentum in International Stock Returns. Journal of Financial Economics 105, 457 - 472.

Ferguson, M. F. and R. L. Shockley (2003). Equilibrium "Anomalies". Journal of Finance 58, 25492580.

Ferson, W. E. and C. R. Harvey (1993). The Risk and Predictability of International Equity Returns. Review of Financial Studies 6, 527 - 566.

Fratzscher, M. (2002). Financial Market Integration in Europe: on the Effects of EMU on Stock Markets. International Journal of Finance and Economics 7, 165-193.

Harvey, C. R. (2000). The drivers of expected returns in international markets Emerging Markets Quarterly 3, 32 - 49.

Henry, P. B. (2000). Stock Market liberalization, Economic Reform, and Emerging Market Equity Prices. Journal of Finance 55, 529-564.

Hou, K., G. A. Karolyi, and B. C. Kho (2011). What Factors Drive Global Stock Returns? Review of Financial Studies 24, 2527- 2574.

Keppler, M. and H. D. Traub (1993). The Small-Country Effect: Small Markets Beat Large Markets. Journal of Investing 2, 17 - 24.

Lambert, M., Fays, B. and Hübner, G. (2020). Factoring Characteristics into Returns: A Clinical Study on the SMB and HML Portfolio Construction Methods. Journal of Banking and Finance, 114.

Lambert, M. and Hübner, G. (2015). Size Matters, BookTo-Market Does Not! The Fama-French Empirical CAPM Revisited. Working Paper.

Leahy, M. P. (1998). New Summary Measures of the Foreign Exchange Value of the Dollar. Federal Reserve Bulletin, 811 - 818.
Li, J. (2021). What Drives the Size and Value Factors? Working Paper.

Rouwenhorst, K. G. (1999). Local return factors and turnover in emerging stock markets. Journal of Finance 54, 1439 - 1464.

Serra, A. P. (2003). The cross-sectional determinants of returns: Evidence from Emerging Markets' Stocks. Journal of Emerging Market Finance 2, $123-162$.

Van der Hart, J., E. Slagter, and D. Van Dijk (2003). Stock Selection Strategies in Emerging Markets. Journal of Empirical Finance 10, 107 - 134. 